International Journal of Social Science and Economic Research

ISSN: 2455-8834

Volume:06, Issue:03 "March 2021"

\title{
MYANMAR'S MILITARY COUP: IMPACT ON INDIA
}

\author{
Joy Chowdhury \\ M.A in Political Seience (B.U), Research scholar, NTA Net and SET (W.B) \\ DOI: 10.46609/IJSSER.2021.v06i03.005 URL: https://doi.org/10.46609/IJSSER.2021.v06i03.005
}

\begin{abstract}
In this Paper we're going to study about Myanmar 's military coup why did it happen and who is going to benefit from it . Located towards the eastern part of India and so Myanmar is known as the Gateway to the east or it is also known as the Gateway to the ASEAN. we can mention as the gateway to ASEAN or Gateway to the east also if we would see its location it is our Eastern neighbor and it is also our neighbor like the immediate land boundary neighbor so foreign policies of India converge at mine mod first as the act East policy of the Government of India and another is the neighborhood first policy. so both these foreign policies both these tools of foreign policy converge at man mark. due to lack of proper economic growth extensive poverty military dictatorship and prolonged civil war in fact in the early 1960s Myanmar was the richest country in Asia with wealthy natural resources but then it closed its economy to the outside world and is now the poorest country in the region. Myanmar closed its economy because Myanmar was under the military rule from 1962 to 2011. It was only in 2010 Myanmar slowly started moving from military rule to partial democracy and the reason behind that move was due to the increasing pressure from the western countries the u.s and many other western countries had put sanctions on Myanmar while it was under the military rule .Myanmar military had no other option but to open. In this study we will focus military coup in Myanmer and its impact on India.
\end{abstract}

Keywords: dictatorship, military coup, partial democracy, ASEAN, Act east.

\section{Introduction}

India is a very large border with Myanmar almost for Indian states as the two provinces of Myanmar that is the sagging and chin provinces of Myanmar as well as the history is concerned .so Myanmar gained independence from the British as almost at the same time when India gained independence India gained it in August 1947 and Myanmar gained after 11 months in July 1948 so there was independence but there was some ethnic conflicts in Miami at that time . but even though nonetheless there was democracy there was Constitution and a democratically 


\section{International Journal of Social Science and Economic Research}

ISSN: $2455-8834$

Volume:06, Issue:03 "March 2021"

elected government ruled man mark however in 1962 General Lee actually led a military coup against the democratically elected government and he we know established a military rule that actually ended in 2011 and after that so for about five decades Myanmar was under the military rule and almost all the Western nations had imposed economic sanctions upon Myanmar and because of these sanctions Myanmar actually we know deteriorated its growth was not there and China was the only that was actually present with Myanmar during those during that period of five decades Menma virtually had no partners either in the region or globally because because of the we know dictatorship of the military rulers military generals and lack of democracy human rights violation because of all these reasons there were sanctions and no country wanted to created Menma and hence virtually there was no prosperity in the nation also one of the points that we should keep in mind is that the Myanmar army the Burmese army sought to nationalize everything they sought to bring every means of production under their control be it press be media beat industry be the services sector schools hospitals education everything so that was we know a sense of socialism was there and that dwell of this socialist model from the USSR as well as a central planning was there so there were central istic tendencies unitary tendencies in Myanmar and lack of democracy was there no public opinion was not and it was totally the military rule that was prevailing in the country and hence the country we know the economic situation of the country was really in a dire state and because of this way or these Western sanctions as well as the sanctions by United Nations India actually severed all ties with Myanmar there was virtually no bilateral relationship was strategic relationship between India and Myanmar so we could just imagine that when all the countries are moving away Myanmar is boarded by bangladesh previously the name of this country was burma after 1989 the ruling military government changed the name from burma to Myanmar the capital of Myanmar is napierdo and the estimated population of the country is around 5.4 crores. Myanmar is the largest country in mainland southeast asia some of the main cities of Myanmar are yangon previously it is known as rangoon if we remember the last mughal emperor of india bahadur shah zafar he was found guilty during the 1857 revolt and the british sent him to rangoon for life imprisonment where he died in 1862. Mandalay is another popular city in Myanmar and then of course the capital city or the administrative capital napierdo. Now coming to religion ninety percent of theMyanmar population practices buddhism and that is how it becomes the main religion in Myanmar if we are aware buddhism is divided into three branches theravada buddhism mahayana buddhism and tantric buddhism theravada is believed to be the oldest as well as the most orthodox form of buddhism apart from buddhism there are some who practices christianity islam and hinduism and then comes the remaining population who practices other forms of Buddhism. Myanmar is rich in natural resources that include natural gas petroleum timber and valuable minerals such as gold 10 rupees and jade now we may have a question if Myanmar has so much of natural resources then why is it counted among united nations list of 


\section{International Journal of Social Science and Economic Research}

ISSN: $2455-8834$

Volume:06, Issue:03 "March 2021"

least developed countries ? The answer to that question is development of Myanmar has never been on the right way Myanmar to the outside world it was a case of economic necessity. In 2008 the Myanmar military had made the constitution this constitution was Myanmar 's military's roadmap to democracy that is why we must have heard about this person her name is aung sang suki she was the state councillor of Myanmar which is an equivalent rank to a prime minister and she was also the minister of foreign affairs from 2016 to 2021. She was the daughter of Myanmar 's independence hero general aung san in 1991 she was awarded the nobel peace prize while she was under house arrest she was then released from house arrest in 2010. As i've mentioned after 2010 Myanmar slowly started moving from military rule to partial democracy due to the western pressure that is how in 2015 aung san suki contested in Myanmar 's first openly contested election where she was part of the national league for democracy party her party won the election she then became a popular figure in Myanmar. She was compared with nelson mandela we see mandela served 27 years in prison shortly after his release mandela was chosen as the president of south Africa. In aung san suki case she spent nearly 15 years under house arrest she received the nobel prize when she was under house arrest she became the state council of Myanmar in 2015 which is a similar rank to a prime minister although the Myanmar military accepted the partial democracy move but they still wanted to maintain their authority and supremacy. Myanmar has a bicameral legislature if we look at the lower house of Myanmar legislature it consists of 440 members who are called the members of parliament out of 440 members 330 are directly elected through the first past the post system and the remaining 110 are appointed by the Myanmar armed forces that means the constitution of Myanmar allocated its military at 25 of seats in parliament that further means that the Myanmar military has veto power over constitutional amendments the Myanmar military is not only powerful but also extremely wealthy because they control a lot of companies and have links with industries such as jade and ruby mining then tobacco beer and then manufacturing sector tourism banking transport etc last year on 8th november 2020 .aung san suki again won the general elections let me remind again that she is part of the national league for democracy it is a civilian political party so what happened was on 1 february 2021 she was arrested by the Myanmar military and put under house arrest this is called as a military coup the meaning of the word coup is the removal and seizure of a government and its powers now the question is why did this military coup happen? It is said that the Myanmar military has accused aung san suki and her party nld for doing irregularities and voter fraud in simple words the Myanmar military is appealing to the election body of Myanmar to look into the matter and enquire whether the civilian government which is the nld whether or not they have won the election in a free and fair manner but so far there has been no evidence of voter fraud or malpractice it is also believed that aung san sookie and her party nld wanted to bring some constitutional reforms after the 2020 election through which first thing they wanted to do was to get rid of military role in politics and governance and obviously 


\section{International Journal of Social Science and Economic Research}

ISSN: $2455-8834$

Volume:06, Issue:03 "March 2021"

the military did not like it because this way the military will lose its authority and supremacy in the country and also the fact that 25 of the mps were from Myanmar 's armed forces so to bring any change through constitutional amendment the civil political party has to gather a minimum of 75 percent vote in the parliament only then any amendment or bill would be passed in Myanmar 's parliament .although aung san tsuki's party has the absolute majority by securing a total of 396 seats in the 2020 election the party won 258 seats in the lower house and 138 seats in the upper house to win absolute majority a party needs only 322 seats so 396 is well above the mandatory requirement the main opposition party is the union solidarity and development party it is believed that the usdp is usually military backed and the politicians in this party are former military generals this party has managed to win only 33 seats 26 in the lower house and 7 in the upper house needless to say under Myanmar 's 2008 constitution 25 seat in the parliament are reserved for Myanmar 's armed forces as i've mentioned aung san suki and her party nld wanted to bring some constitutional reforms after the 2020 election apart from that she and her party has also appealed to other ethnic local parties in Myanmar to come together to form a unity government this was the first time that the ruling party had made such an offer another problem for the Myanmar military was that the opposition party that is usdp as i have mentioned it is believed to be a military-backed political party because the mps of this party are mostly former generals even they have voted in large numbers to remove the military veto power in other words in few political matters these former generals were taking the side of aung san suki and her party so all these three reasons were together creating a great concern for Myanmar 's military leadership. What all changes the national league for democracy wanted to bring after winning the 2020 election one of the proposed changes was to lower the minimum required percentage for parliamentary approval for constitutional changes as per the 2008 Myanmar 's constitution 75 of the mps have to be in favor of it the ruling government wanted this number to be at 70 percent the second thing is that Myanmar 's parliament continues to be dominated by the army and former generals so the civil government wanted to bring some constitutional reforms so that they can get rid of military role in politics and governance so these are the main reason behind the military coup in Myanmar now the next question is with respect to international relations.

\section{Critical analysis}

Who is going to benefit out of this military coup let's talk about big nations india is in favor of democratic transition. India does not want to deal with Myanmar 's military when it comes to diplomacy and politics India wants a peaceful and negotiable civil government this is also the reason many of India and Pakistan's diplomatic and political dialogues have never reached any satisfactory conclusion it is due to the involvement of Pakistan's deep state which is basically Pakistan's army political leadership cannot negotiate or talk with military leadership of course both are necessary but when it comes to cross communication a cannot communicate effectively 


\section{International Journal of Social Science and Economic Research}

ISSN: $2455-8834$

Volume:06, Issue:03 "March 2021"

with $b$ a has to communicate with a. So India is in favor of Myanmar 's democratic leadership however it does not mean that the Indian government is against Myanmar 's military because Myanmar 's military has often been supportive and helped India to crack down on northeast militant forces that have their bases set up across the Myanmar borders india shares a long land border of over 1643 kilometers with Myanmar as well as maritime boundary in the bay of bengal four north eastern states Pradesh Nagaland Manipur and Mizoram have a boundary with Myanmar. Myanmar 's military has been supportive and helped India many times the imbak's india Myanmar bilateral army exercise is a regular occurrence that brings both the armies together for joint exercises operations and trainings this is the reason india has maintained close relations with the Myanmar military even after the democratic government came into force .india has also supplied 1.5 million doses of coved vaccines to Myanmar even while the western countries have put pressure against Myanmar 's military leaders following the coup the indian foreign secretary has also said in a statement that india will continue to provide humanitarian assistance to Myanmar .So all of this says that the Indian government has actually no problem against the Myanmar 's military leadership but when it comes to economy trade and development obviously any civil government wants to talk to the opposite country's civil government and not their military leadership but in India Myanmar 's case the Indian government has chosen the middle way by maintaining relationship with both military leaders as well as the civil government coming to china min aung lang who is the current military leader of Myanmar he has openly criticized china for supporting the anti-national armed groups like united va state army and arakan army these anti-national groups are basically terrorist organizations that are acting as china's proxies they also supply weapons to militant groups in India's north-eastern states it is said that all these military groups receive training and weapons from the southern Chinese city of Kunming these military groups travel through the kachin state it is the northernmost state of Myanmar. So these militant groups travel through the northernmost region of Myanmar and enter Indian territory in fact this northernmost region of Myanmar which is called the kachin state it is occupied by many ethnic militant groups they are designated as militant groups by both the Myanmar as well as indian government and the aim of these militant groups is to fight for independence or greater autonomy china takes advantage of them by giving weapons and training first they give it to the armed ethnic groups in Myanmar through them they supply further to the Indian rebel groups in northeastern region in jammu and Kashmir. How the Indian army is fighting the pakistani proxies similarly in the northeastern region of india and in the northern part of Myanmar the armed rebel groups are supported by the chinese and Hence they are also called as chinese proxies so the chinese leadership has nothing to gain from this military coup because Myanmar 's military leadership is not that fond of xi jinping however if we are aware of china-Myanmar economic corridor it is part of china's belt and road initiative wherein china wants to reach the indian ocean passing through Myanmar city of 


\section{International Journal of Social Science and Economic Research}

ISSN: $2455-8834$

Volume:06, Issue:03 "March 2021"

mandalay to the coastal region of kyatpu it is similar to china-pakistan economic corridor that connects china's western province of xinjiang to karachi and gwadar on the arabian sea by developing ports such as gwadar and kyakpu china aims to lower its strategic dependence on the malacca streets presently almost 90 of chinese trade passes through the south china sea this is the reason china is making more economic corridors like cpec and cmec by doing dead trap diplomacy so what i'm trying to say is that the chinese leadership has been very cordial with myanmas aung san suki's democratic government. Last year together they have signed many deals in areas such as politics trade investment and communication in fact many people in Myanmar especially the weth are protesting because they feel china is involved in supporting Myanmar 's military coup however it is difficult to see any angle as to how china can benefit from this coup as china had solid relations with the civil government china also stood by aung san tsuki's government when it faced international backlash over the crackdown on rohingya muslims so in many ways the relationship between china and Myanmar has been stable under aung san tsuki's leadership .so i don't think a military coup in Myanmar is in china's interest in fact china needs Myanmar to be normal and stable country only then china can succeed in its economic and strategic plans now that's a whole different matter if china is holding a secret friendship with Myanmar 's military leadership only time will tell and if it is true then india will know about it and respond accordingly as of now india is silent on this issue and it also wants to remain neutral because it has friendly relations with Myanmar 's civil government as well as the military leadership so as of now it looks only the Myanmar military has everything to gain myanmas military is also known as the junta. They want to maintain their supremacy and authority in the country as i've mentioned earlier that the civil government wants to bring constitutional reforms that would include getting rid of the military rule in politics and governance so obviously this is not acceptable to the military leadership and that is why they overthrew the civil government now Myanmar 's military is using a state of emergency to take control for one year and it has also promised to hold fresh elections afterwards .now what about the western countries they have nothing else to do other than imposing sanctions on Myanmar and $\mathrm{i}$ think president joe biden has said in a statement that the u.s will reinstate sanctions on Myanmar if the country's military does not stop all of this and $\mathrm{i}$ believe canada and united kingdom has also imposed sanctions on Myanmar see canada usually follows whatever united states say. Now the reason united kingdom has imposed sanction is because aung san suki's late husband was a british citizen basically she married a british citizen so her children are also british citizens whether she has dual citizenship or not anyhow as she married a british citizen that is why she was not made the president of Myanmar she was made the state councillor of Myanmar a new position was created for her also the fact that aung san suki has close relation with the british parliament so anyhow that is the reason behind uk's sanction on Myanmar but author don't think Myanmar 's military leadership cares of u.s sanctions or any other western 


\section{International Journal of Social Science and Economic Research}

ISSN: $2455-8834$

Volume:06, Issue:03 "March 2021"

countries sanctions even during the rohingya crisis the west collectively condemned the actions of Myanmar 's military and in return Myanmar did not care about it and there is a reason for that too as we all know two big countries that is india and china both are neighbours of Myanmar and they both hold neutral views towards Myanmar 's civil as well as military leadership and i don't think so Myanmar as a country has huge ambition of becoming a superpower that is why they don't care what the west thinks about them as long as india and china the two neighbours benefit Myanmar and Myanmar is beneficial for them that's all as a country Myanmar needs so let's see what happens with time alright then that was everything we had to know about the Myanmar 's recent military coup

\section{China Factor}

but China is taking advantage of this void this wacom that has been created by elimination of all the countries so China actually played a very smart card here it we know when all the countries eliminated when all the countries exited Myanmar their strategic relations were not there and even the consular generals and the embassies of different countries were shut down in Myanmar so China took the advantage of this situation and it actually supported the military regime in Myanmar it invested heavily in that particular country to enhance its influence so basically we must be knowing that we know 1962 is the same year when India and China for the world and 1962 is the same year when military coup took place in Burma and we know the military rule was established so we could just see the linkages that both the events happen at the same time and so China's or to we know enhance its strategic influence in the Indian neighborhood and till 1962 Indian men were had a good relation but after the military coup and the saying and the sanctions by the Western nations so India and man were distance we know distance was there there was not really warmth in the relationship and so China took advantage of this and it tried to enhance its strategic influence and now the influence of China is such that it is we know it has established the oil and gas terminals from from Myanmar till China to bypass the Malacca Strait this is the map showing we know from Bay of Bengal the oil and gas corridor the oil and gas terminal started and Rigo still China in nanning so basically this is to reduce the dependency of China on the Malacca Strait for energy imports and to enhance the energy security and apart from that China is we know extensively investing money in Myanmar also it has now acquired the how few islands of Myanmar to establish them as a commercial hub and to to basically bring them within the global supply chain so Yahoo Islands we know a lie of the coast of Myanmar in the Bay of Bengal so these islands have been acquired by China too actually so basically that would be developed as the commercial hub and also that would be integrated into the one belt one Road initiative of China of which India and Bhutan are not the members and India has not joined one belt one Road initiative because of the sovereignty issues because the china-pakistan economic corridor passes through Pakistan Occupied Kashmir well that's a different matter 


\section{International Journal of Social Science and Economic Research}

ISSN: $2455-8834$

Volume:06, Issue:03 "March 2021"

altogether so now coming to the yahooooo Islands also China's establishing industries and the special economic zones in Myanmar so basically China has extended its strategic as well as the economic influence over Myanmar it has invested heavily in the nation and since the military time since the time when there was no partner of Myanmar globally China has been a reliable partner of man we're introduced because of this reason that we know there have been close linkages between china and Myanmar but one of the points that we should notice here that people also have some sort of bitter feeling regarding China because China at that point of time supported the suppressive military power the suppressive military rule that was against the human rights and the democracy and so it was because of this reason that some of the people view China with suspicion in Myanmar now coming to the india manma dynamics and what india can do to gained its strategic influence in the region there are four dimensions on which India can focus one is the development cooperation another is a trade and investment thought is a cultural portion and fourth as a security and defense we would look at all four of them one by one and using these four parameters India can regain its strategic space in the region so coming to the developmental cooperation first of all we know the foremost and the most important part of the developmental cooperation are the four infrastructure projects at India's currently undertaking in Myanmar one is the color than multimodal transit project and others the 69 bridges on tamuka Leyva Road and caliber yagi Road both these roads are basically part of the trilateral highway of India Myanmar and Thailand and another is the victim Road this road is basically being constructed in the Qin province of Myanmar that adjoins a man must miss Rama state of India so these are the major infrastructure projects that India is undertaking but these projects have been lagging behind time these projects have not been completed and now the Indian government has said the time limit of 2020 to complete all these four projects so that the connectivity project a connectivity between India and ASEAN and India and the Southeast Asia can be enhanced and also there can be visible we know the visible results on ground of the in domain master teacher cooperation apart from that as we know that the northeastern part of India touches the Myanmar the four states of northeastern India touch Myanmar so basically we know one of the focus areas should be the close cooperation between the northeast India and the western portion of Myanmar the portion that lies towards the west of the Irrawaddy River in Myanmar so both these areas the northeastern part of India and the western part of Myanmar are under 20 okay so now since they share border so both the country should focus on the joint people-to-people business-to-business contacts developing a bus service from northeastern towards the western part of Myanmar single window clearances for transport of goods and services also liberal visa is a regime so that the people can move from one place to another for economic ties also the joint development of the border hearts and also we know the tourism can be promoted in the Northeast and India beat the medical tourism or the recreational tourism the government of india has recently set up different medical facilities including the homeopathy and 


\section{International Journal of Social Science and Economic Research}

ISSN: $2455-8834$

Volume:06, Issue:03 "March 2021"

Ayurveda Center at Shillong the sports facility at money put the film and television Institute of India Arunachal Pradesh so all these sorts of tourism's can be promoted across the border so that there can be more movement and transit of goods and people and also more employment can be generated this would lead to we know a greater economic cooperation between the people of the northeastern India and the western mama so this would actually lead lead to a flow of money and when the cash flow would take place automatically prosperity would come to the region also India is currently focusing on the capacity-building in Myanmar Myanmar Institute of information and Technology has been established with the assistance of crippled IT Bangalore and also the placements that are offered at mwt are very convincing and almost all the students are being placed also an agriculture research and education Institute has been set up with the help of Indian Council for agricultural research apart from this India is also undertaking some small capacity building projects for imparting the skills regarding the training textile health facilities IT and other areas as far as the trade and investment is concerned so trade and investment is we know a low-key affair between India and Myanmar Myanmar basically exports the agro products or the forest products to India and it is because of this reason that the trade has remained low and currently the traders of the order of two billion dollars how India in 2012 had set up the target to take that weight to three billion dollars and mostly the products that exports to India are the pulses and the gram so basically we know the pulses import from Myanmar is essential for the food security of India and also 90 percent of the pulses that are produced in Myanmar is ported to India so the Burmese farmers have actually found a very huge market for pulses in India apart from the huge market for farmers the foreign exchange that we know that comes into Manoir as a part of the export of pulses to India is also very significant so because of all these reasons Myanmar is a bit dependent upon India but recently due to the excessive pulse reduction in India and falling off the pulse prices India had put some restrictions on the import of pulses from India from outside and so because of this reason the farmers in the Myanmar have been hit because India has suddenly put restrictions upon the pulse import to protect our own farmers apart from that India can also open the market for rice import from Myanmar currently man Mar exports modes or most of its rice products to China and but China as we would be knowing that we know the market access in China is a difficult thing and they put several trade or tariffs and non-tariff assistance basically the trade barriers to rice imports from Myanmar .

\section{Concluding Observations and Recommendations}

Increasing India's visibility in Myanmar is extremely important towards building a more constructive bilateral relationship.

- Road connectivity between both countries has a lot of room for improvement and expansion. 


\section{International Journal of Social Science and Economic Research}

ISSN: $2455-8834$

Volume:06, Issue:03 "March 2021"

- Air connectivity needs to be systematised more with frequent flights, more options of airlines, and cheaper fares.

- The aspect of religious tourism needs to be explored by increasing the number of direct flights from Yangon/Mandalay/Naypidaw to Gaya and other places in Eastern India.

- India can invest in and explore the health sector in Myanmar including the setting up of improved hospitals, clinics and technical institutions in healthcare. Indian pharmaceutical companies can be encouraged to take in interest in this area especially because Indian pharmaceutical products are in good demand in Myanmar.

- Joint military operations at regular intervals are necessary to keep a check on militancy, smuggling and illegal entry into either country.

- The importance of establishing maritime connectivity with Myanmar needs attention. Besides the KMMTTP, the Indian government is also considering port connectivity (mentioned previously) for trade in goods. Maritime links could greatly reduce the cost of trade and this should be explored further.

- Inter-country passenger cruise service for the purpose of tourism can be considered.

- Suitable and relevant norms need to be worked out for better functioning of border haats and border trade. For instance, measures to boost cross-border trade could include more local products which would likely enhance economic activity in India's Northeast as well as in the bordering regions of Myanmar.

- Infrastructural facilities at border crossing points need to be upgraded to respond to security needs as well as to provide facilities like warehousing and banking.

- In the education sector, both countries can improve existing modalities of exchange and cooperation and enhance possibilities. For instance, the ability to use the English language is neither strong nor prevalent in Myanmar and this is one area where India can help

- India can also provide assistance in imparting technological knowledge and related vocational skills. Select institutions and universities in both countries should be encouraged by respective governments to introduce courses not only in the field of technology but also in the areas of historical, cultural and language studies. India particularly can think of instituting a scholarship programme for Myanmarese students in colleges and universities in eastern and northeastern India. 


\section{International Journal of Social Science and Economic Research}

ISSN: $2455-8834$

Volume:06, Issue:03 "March 2021"

- Both countries need to explore and encourage bilateral tourism especially through package tours. Select tourist agencies may be encouraged to publicise areas of interest for targeted populations in either country and to provide tour packages at affordable prices.

- Measures to legalise informal trade and create suitable institutions and regulations for it including the use of both currencies as legal tender in border areas would be an important step forward.

- It might be useful for India to revisit norms that regulate border trade but which also limit the potential of the same and thus constrict the extent of trade that takes place. Fresh and meaningful regulations that would be better suited to contemporary situations may therefore be developed. For instance the items permissible for such trade could be revisited and revised.

- Creation of local resource based network with local tribal skills on both sides of the border can pave the way to strengthen cooperation and trust between these two states.

- Since the border shared between the two countries is largely porous, it is necessary to enforce mechanisms that would monitor the flow of migrant labour and also examine the entry and exit of narcotics and smuggled items.

Both countries can also collaborate in the establishment of early-warning and management systems for natural disasters. There is a demand for electricity in the less developed border towns in Myanmar, and India can help Myanmar to meet the demand by supplying electricity across the border. If it happens - and there is no reason why it should not - then it will be a unique crossborder power trade when no such electricity trade between Myanmar and its other neighbours has been talked about. Moreso, electricity must be considered as a commodity while generation and transmission must be treated as services and this trade will act as a major confidence building measure.

\section{Conclusion}

India can also support Myanmar by opening the access to rice market of India but then also we know again the interest of our farmers would be at stake so basically what we can do is we can diversify our trade and also the investment in Myanmar we currently are focused only on the oil in the natural gas sector but we can invest more in the we know steel cement power take sell all these sectors and then the trade can also be divert to a diversified into different raw materials and finished and value-added product so this trade and investment needs to be enhanced as well as the cultural ties are concerned so recently an under temple of we know the Buddhist temple of began area of Myanmar has been restored by the Archaeological Survey of India also both care 


\section{International Journal of Social Science and Economic Research}

ISSN: $2455-8834$

Volume:06, Issue:03 "March 2021"

is one of the most holiest places of religion for man marries Buddhist so buddhist diplomacy can be undertaken to enhance the people-to-people contacts and also to promote tourism from one country to another and it would also enhance the strong cultural linkages and the historical linkages that both the countries here so cultural has a dominant role to play here because buddhism originated in india and so every buddhist in Myanmar would at some point of time would like to visit both gear which is the holiest place for buddhist and so the buddhist diplomacy can be taken to another level by a deeper cooperation as well as the security cooperation is concerned so I would first we know like to highlight the Rohingya issue Rohingyas as I had already discussed in my previous lessons that row india ethnic groups are being targeted by the Myanmar ease military forces and also it poses a threat to the color done multimodal transit project because we know Rohingya issue is currently taking place in the Rakhine province and the capital is sit away and the Culloden multimodal project passes through the city way port and so it is because of this reason there are disturbances and there State are a threat to the colored and multimodal project also recently Aung San su Chi the state councilor of Myanmar had requested the coffee and Han foundation to submit a report on the Rakhine province and so on Advisory Commission under the chairmanship of a coffee and nan was formed and the coffee and on Commission actually laid down the report that we know the Burmese government should not use force rather than using the force against our India's it should focus on the holistic and the comprehensive development of the Rakhine province and also provide access to we know better trade means better economic facilities right to movement right to vote and even we won't imagine that we know the the Rohingyas in Myanmar have not been given the citizenship as well as the laws of the 1980s concerned Rohingyas are not the legitimate citizens of Myanmar so they don't have passport and it though don't they cannot move from one place to another legitimately and just because of this reason that they are facing operation in Myanmar and though they don't have anywhere to go except for being refugees to Myanmar to Bangladesh Thailand Malaysia and India so basically the condition of Rohingyas is very pathetic also we know some of the Indian insurgent groups including NECN Kaplan are taking shelter in Myanmar and so Myanmar government has been cooperating with India to eliminate the cross-border terrorists that i've been taking shelter in Myanmar army and also the surgical strikes was conducted across the money poor border when in the Channel District of money for the NSE and coupling faction had attacked the armed forces there so this is a multi-faceted relationship between India and Myanmar and the visit of Prime Minister Narendra Modi would go a long way in deepening it and reclaim the strategic space of India that we have lost to China thank we very much. 
International Journal of Social Science and Economic Research

ISSN: 2455-8834

Volume:06, Issue:03 "March 2021"

\section{References}

1. Gottschlich P. New Developments in India-Myanmar Bilateral Relations? Journal of Current Southeast Asian Affairs. 2015;34(2):139-163. doi:10.1177/186810341503400206

2. Majumdar M. India-Myanmar Border Fencing and India's Act East Policy. India Quarterly. 2020;76(1):58-72. doi:10.1177/0974928419901190

3. Sharma S. Negotiating Transnational Identities on Indo-Myanmar Border: The Trade Factor. India Quarterly. 2011;67(1):53-64. doi:10.1177/097492841006700104

4. Choudhary LK. Indo-Myanmar Relations: Retrospect and Prospect. India Quarterly. 2005;61(4):143-168. doi:10.1177/097492840506100406

5. Biswas NR. Myanmar's military and the garrison state: State-military relations in Myanmar and their influence in the [re]production of violence against minorities. Asian Journal of Comparative Politics. 2020;5(2):158-173. doi:10.1177/2057891119880261

6. Jha GK, Banerjee A. India-Myanmar Relations: Coming off the Circle. South Asian Survey. 2012;19(1):79-99. doi:10.1177/0971523114539583

7. Hervik P, Kahn HE. Scholarly Surrealism: The Persistence of Mayanness. Critique of Anthropology. 2006;26(2):209-232. doi:10.1177/0308275X06064994

8. A. Outline of the Second Bangladesh-China- India-Myanmar (BCIM) Forum, New Delhi, 4-7 December 2000. China Report. 2001;37(2):255-257. doi:10.1177/000944550103700209

Website:

https://www.orfonline.org/expert-speak/myanmar-india-relations-upswing/ https://idsa.in/taxonomy/term/473

https://thediplomat.com/tag/india-myanmar-relations/

https://www.e-ir.info/2020/03/31/a-geostrategic-explanation-of-india-myanmar-bilateralrelations-since-the-1990s/

https://moderndiplomacy.eu/2020/12/15/understanding-the-india-myanmar-relations/

https://www.gatewayhouse.in/shifting-india-myanmar-relations/

https://www.iiss.org/blogs/analysis/2018/05/india-myanmar-china-relations 
International Journal of Social Science and Economic Research

ISSN: 2455-8834

Volume:06, Issue:03 "March 2021"

https://economictimes.indiatimes.com/topic/India-Myanmar-Relations

https://www.firstpost.com/tag/india-myanmar-relations

\section{Books:}

1. Jhadav,k. (India Myanmar Relations Hardcover - 1 January 2019), Publisher:Gaurav Book Centre Pvt

2 Basu ,A.Ray Chaudhury \& Basu,P. India-Myanmar Connectivity: Possibilities and Challenges, , Observer Research Foundation, Kolkata

3. Ghosh,L. India-Myanmar Relations: Historical Links to Contemporary Convergences Edited 2016

4. Bhatia ,R.INDIA-MYANMAR RELATIONS: CHANGING CONTOURS Hardcover (1 September 2015), Routledge (India)

5. Nguyen Tuan Binh (INDIA - MYANMAR RELATIONS (1992 - 2014): THE IMPACTS OF INDIA'S FOREIGN POLICY ADJUSTMENT Paperback - July 8, 2020), LAP LAMBERT Academic Publishing (July 8, 2020) 